\title{
Serum Alkaline Phosphatase Levels in Healthy Korean Children and Adolescents
}

\author{
Se-Young Kwon and Young-Ak Na \\ Department of Biomedical Laboratory Science, Daegu Health College, Daegu 702-722, Korea
}

\begin{abstract}
Children and adolescents normally have higher Alkaline phosphatase levels than adults. This study was conducted to provide basic data about pediatric reference intervals for ALP. The data from the 2011 Korean National Health and Nutrition Examination Survey was used. Analysis was done for 847 Children and Adolescents ( 443 boys and 404 girls) aged 10 to 19. The method of $p$-NPP \& EAE buffer was used to get the data. The highest ALP levels were found in boys aged 12 to 13 , the reference interval being $653 \sim 1,518 \mathrm{IU} / \mathrm{L}$; the levels decreased for those over 13 years old. In the case of girls, the highest ALP levels were found with those aged between 11 and 12, the reference interval being 463 1,598 IU/L; the levels decreased after 12 years of age. The mean difference in all age groups was statistically significant, except for those aged 10 to 11 and 11 to 12 . Therefore, it is suggested that pediatric reference intervals should be divided into three groups according to gender. Complementing data about children and adolescents below 10 years old were not included in this study and will be much needed in the next trial.
\end{abstract}

Keywords: Alkaline phosphatase, Children \& Adolescent, Reference intervals

This is an Open Access article distributed under the terms of the Creative Commons Attribution Non-Commercial License (http://creativecommons.org/licenses/by-nc/3.0) which permits unrestricted non-commercial use, distribution, and reproduction in any medium, provided the original work is properly cited

Copyright (C) 2014 The Korean Society for Clinical Laboratory Science. All rights reserved.
Corresponding author: Se-Young Kwon Department of Biomedical Laboratory Science, Daegu Health College, Daegu 702-722, Korea Tel: 82-53-320-1362

E-mail:sykwon@dhc.ac.kr

Received: August 21, 2014

Revised: September 16, 2014

Accepted: September 16, 2014

\section{서 론}

Alkaline phosphatase (ALP)는 pH 9 10.5에서 최적 활성을 나타내며 인산모노에스터(phosphomonoester)의 가수 분해를 촉매하는 효소(EC 3.1.3.1)로서 거의 모든 조직에서 광범위하게 존 재하며 콩팥, 소장, 빼, 태반, 간 등에서 활성이 높아(Kruse 등, 1977; Plomteux와 Reginster, 1980) 그와 관련된 질환에서 증가 한다고 알려져 있다(Lott와 Wolf, 1986).

ALP는 Robinson (1923)과 Kay (1929)와 같은 초기 연구자들 에 의해 빼 질환에서 혈청 ALP의 활성이 높아지는 것이 밝혀지면 서 뼈 질환의 진단에 이용하기 시작했는데, Kay (1930)는 $\beta$-glycerophosphate를 기질로 하여 증명하였고, 이후 Bowers와 McComb (1966)가 수정 보완된 kinetic assay를 제안하였으며, Hausamen 등(1967)은 완충액으로 diethanolamine을 사용하여 측정 방법을 개선하였다. 현재 ALP 활성 측정법은 오래전부터 사 용되어 온 방법(King과 Armstrong, 1934; Shinowara 등, 1942; Bessey 등, 1946; Kind와 King, 1954; Moss, 1966) 뿐 아니라 전
류측정법, 전위차 측정법, 전기영동법, 고성능 액체크로마토그래 피법(Togari 등, 1987) 등 다양한 방법이 사용되고 있으며 여러 질 환 중에서도 주로 뼈 질환과 간담도 질환에 적용되고 있다. 뿐만 아 니라 이러한 방법들을 통해 정상적으로 뼈 성장이 왕성한 성장기 소아나 청소년기에 그 활성치가 증가함이 밝혀졌다(kaplan, 1972; Penttila 등, 1975; Fleisher 등, 1977; Schiele 등, 1983).

하지만 현재 국내 검사기관에서 사용하는 측정방법도 다양할 뿐 아니라, 혈청 ALP의 생리적 변동이 성인의 3 4배까지 상승할 정 도로 성장기 소아에 높고 소아 청소년의 연령에 따른 ALP의 활성 변동이 크게 나타남에도 불구하고 연령에 따른 참고치에 대한 자료 는 미흡한 실정이며 부적합한 참고범위의 사용으로 유아 및 청소년 에서 종종 진단의 오류를 범할 수도 있어 적합한 참고범위의 설정 이 중요하다.

이에 본 연구에서는 10 세 이상 20 세 미만 소아청소년의 연령과 성별에 따른 혈청 ALP의 활성치를 살펴봄으로써 참고치 설정을 위 한 기초 자료를 제시하고자 하였다. 


\section{재료 및 방법}

\section{1. 연구 대상}

2011년 1월부터 12월까지 시행된 국민건강영양조사에서 10세 이상 20 세 미만 연령의 소아청소년 총 1,008 명 중 ALP 측정 결과가 누락된 결측치와 간 및 뼈 질환이 있는 대상자를 제외한 총 847 명 (남자 443명, 여자 404명)의 데이터를 대상으로 하였다. 본 연구는 질병관리본부 연구윤리심의위원회의 승인을 받아 수행된 조사 자 료(승인번호: 2011-02CON-06-C)를 대상으로 분석을 시행하였 다.

\section{2. 연구 방법}

혈액 검사는 8시간 이상 공복 상태에서 대상자들의 정맥 채혈을 시행하였으며, ALP 검사의 측정 시약은 Pureauto S ALP (Sekisui/ JAPAN)를 사용하여 효소법으로 측정하였다. 효소 활성 측정 시약 의 완충액 성분은 ethyl amino ethanol (EAE)이며 기질은 $p$-nitrophenyl phosphate ( $p$-NPP)가 사용되었고 성인의 참고 정상치는 120-370 U/L이다. 측정 장비는 Hitachi 7600 (Hitachi high-technologies Co., Tokyo, Japan) 자동화학 분석기를 사용 하였다.

\section{3. 통계 분석}

본 연구 대상자의 연령에 따른 ALP 활성치의 분포를 살펴보기 위해 각 연령별 $\mathrm{ALP}$ 의 평균, 중앙값, 표준편차(SD), 평균에 대한 95\% 신뢰구간(lower limits, upper limits), 최소값과 최대값에 대 한 기술통계를 제시하였으며, 연령별 ALP의 백분위수를 2.5 백분 위수(2.5th percentiles)에서 97.5백분위수(97.5th percentiles)

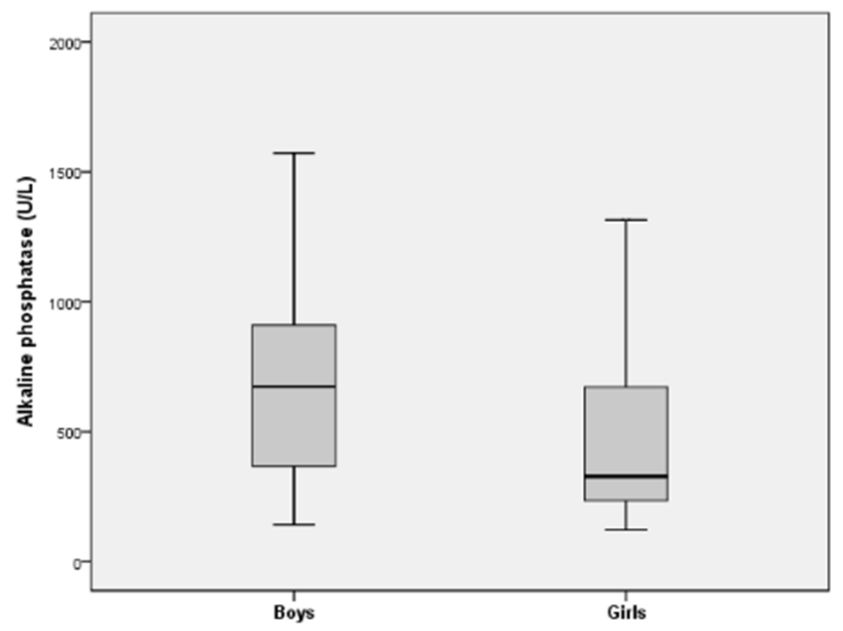

Fig. 1. Distribution of ALP levels for those aged between 10 and 19 by gender (Mean and $95 \% \mathrm{CI}$ ). The mean difference by gender were statistically significant $(p<0.05)$. C.I, confidence interval.
까지 구간별로 나누어 구하였다. 연령별 ALP의 차이는 성별에 따라 나누어 ANOVA (one-way)를 이용하여 분석한 후 Tukey HSD사 후 검정을 시행하였다. 10 세 이상 20 세 미만이 포함된 본 연구에서 연령의 구분은 만연령으로 하였으며, 10 세는 10 세 이상 11 세 미만 을 나타낸다. 그래프는 남녀 연령별 ALP의 분포에서 나타난 기술통 계량들을 box plot으로 제시하였다. 각 연령별 ALP의 남녀간의 차 이는 독립표본 T-검정(independent T-test)을 시행하였다. 자료 에 대한 통계분석은 SPSS 17.0 (SPSS, Inc., Chicago, IL, USA)을 사용하였으며, 결과 해석 시 $p$ 값은 0.05 미만을 유의한 것으로 판 정하였다.

\section{결 과}

성별과 연령에 따른 ALP 활성치의 비교에서 전체 대상자 847 명 중 남아 443 명의 평균은 $671 \mathrm{U} / \mathrm{L}$, 여아 404 명의 평균은 $473 \mathrm{U} / \mathrm{L}$ 로 남아의 평균치가 여아보다 더 높았으며 성별에 따라 통계적으로 유 의한 차이를 보였다 $(p<0.05)$ (Fig. 1).

남아의 경우 혈청 ALP의 평균치는 12 13세에서 1,007 U/L ( $\min 648 \mathrm{U} / \mathrm{L}, \max 1,527 \mathrm{U} / \mathrm{L}$ )로 가장 높았으며, 그 다음 13 14 세에 $962 \mathrm{U} / \mathrm{L}(\min 484 \mathrm{U} / \mathrm{L}, \max 1,521 \mathrm{U} / \mathrm{L})$ 로 높게 나타났고 이 후 연령이 증가할수록 감소하였는데, 17 18세에 평균 $371 \mathrm{U} / \mathrm{L}$ 로 감소하면서 이후 성인의 혈청 ALP수준으로 감소하는 양상을 보였 다(Fig. 2).

여아의 경우 혈청 ALP의 평균치는 $11 \sim 12$ 세에서 $894 \mathrm{U} / \mathrm{L}$ ( $\mathrm{min}$ $452 \mathrm{U} / \mathrm{L}, \max 1,616 \mathrm{U} / \mathrm{L})$ 로 가장 높았으며, 그 다음 $10 \sim 11$ 세에

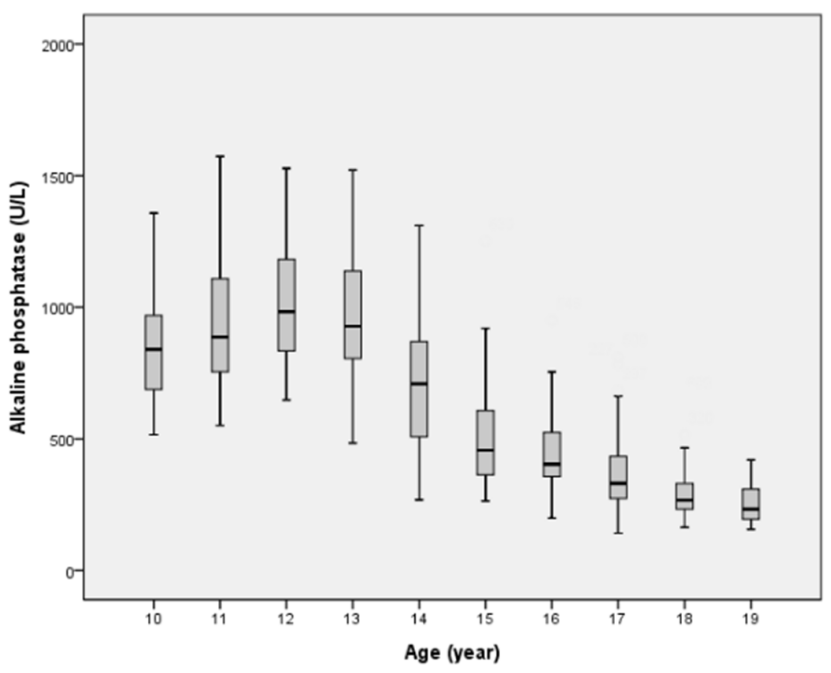

Fig. 2. Change of ALP levels for the boys aged between 10 and 19 (Mean and 95\% Cl). The highest ALP levels were found in boys aged 12 to 13 years, and the reference intervals were $653 \sim 1,518$ $\mathrm{U} / \mathrm{L}$. While the levels showed decrease to those over 13 years old. C.I, confidence interval. 


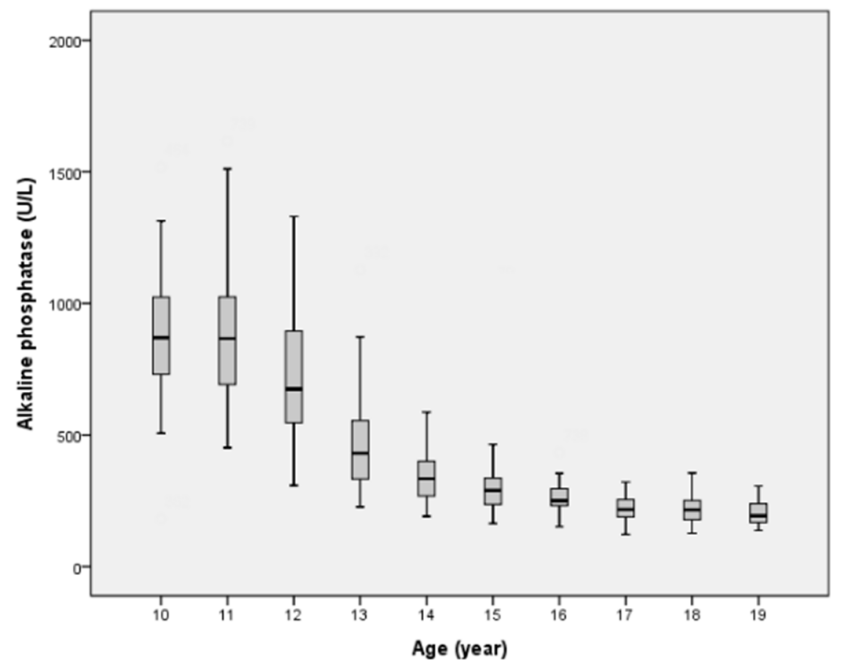

Fig. 3. Change of ALP levels for the girls aged between 10 and 19 (Mean and 95\% Cl). The highest ALP levels were found at those aged between 11 and 12, and the reference intervals were 463 $1,598 \mathrm{U} / \mathrm{L}$. While the levels showed decrease after 12 years old. C.I, confidence interval.
$878 \mathrm{U} / \mathrm{L}$ ( $\min 181 \mathrm{U} / \mathrm{L}, \max 1,517 \mathrm{U} / \mathrm{L}$ ) 로 높게 나타났고 이후 연 령 증가에 따른 감소를 보이다가 14 15세에 평균 $340 \mathrm{U} / \mathrm{L}$ 로 감소 하면서 이후에 성인의 혈청 농도 수준으로 안정화되었다(Fig. 3) (Table 1).

각각의 연령군에서 성별에 따른 ALP 활성치의 평균을 비교한 결 과 $10 \sim 11$ 세, $11 \sim 12$ 세의 경우 통계적으로 유의한 차이를 보이지 않았으나, 이를 제외한 나머지 모든 연령군에서 평균값의 차이는 통계적으로 유의하였다 $(p<0.001)$. 그리고 남녀 각각의 성별군 내 에서 평균의 차이를 다중비교를 통해 사후분석한 결과 남아의 경우 10 13세, $14 \sim 16$ 세, $17 \sim 19$ 세 연령군에서, 여아의 경우 10 12 세, 13 15세, 16 19세 연령군에서 각각 비유의성이 검증되었다 (Table 2).

참고범위 설정을 위해 성별과 연령에 따라 2.5 백분위수와 97.5 백분위수를 비롯하여 각 백분위수(\%)에 따라 활성치의 분포를 살 펴본 결과, 남아 $11 \sim 12$ 세의 경우 2.5 백분위수와 97.5 백분위수에

Table 1. Mean serum alkaline phosphatase levels, median, SD, Minimum and Maximum values according to age groups (U/L)

\begin{tabular}{|c|c|c|c|c|c|c|c|c|c|c|}
\hline & \multirow{2}{*}{ Age (yr) } & \multirow{2}{*}{$\mathrm{N}$} & \multirow{2}{*}{ Median } & \multirow{2}{*}{ Mean } & \multirow{2}{*}{ SD } & \multirow{2}{*}{ SE } & \multicolumn{2}{|c|}{$95 \%$ C.I. of mean } & \multirow{2}{*}{ Min } & \multirow{2}{*}{ Max } \\
\hline & & & & & & & Lower & Upper & & \\
\hline \multirow[t]{11}{*}{ All } & 10 & 95 & 854 & 857 & 218 & 22 & 812 & 901 & 181 & 1,517 \\
\hline & 11 & 88 & 879 & 913 & 244 & 26 & 861 & 965 & 452 & 1,616 \\
\hline & 12 & 101 & 869 & 886 & 274 & 27 & 832 & 940 & 308 & 1,527 \\
\hline & 13 & 92 & 703 & 718 & 328 & 34 & 650 & 786 & 227 & 1,521 \\
\hline & 14 & 90 & 493 & 559 & 276 & 29 & 501 & 617 & 191 & 1,310 \\
\hline & 15 & 87 & 368 & 429 & 201 & 22 & 386 & 471 & 164 & 1,251 \\
\hline & 16 & 76 & 301 & 342 & 147 & 17 & 309 & 376 & 152 & 950 \\
\hline & 17 & 92 & 255 & 291 & 130 & 14 & 264 & 318 & 122 & 809 \\
\hline & 18 & 68 & 251 & 262 & 90 & 11 & 240 & 283 & 127 & 650 \\
\hline & 19 & 58 & 203 & 223 & 64 & 8 & 207 & 240 & 137 & 420 \\
\hline & Total & 847 & 486 & 577 & 340 & 12 & 554 & 599 & 122 & 1,616 \\
\hline \multirow[t]{11}{*}{ Boys } & 10 & 52 & 840 & 839 & 194 & 27 & 785 & 892 & 516 & 1,358 \\
\hline & 11 & 42 & 887 & 934 & 226 & 35 & 863 & 1,004 & 551 & 1,573 \\
\hline & 12 & 57 & 983 & 1,007 & 227 & 30 & 947 & 1,068 & 648 & 1,527 \\
\hline & 13 & 46 & 928 & 962 & 245 & 36 & 889 & 1,034 & 484 & 1,521 \\
\hline & 14 & 54 & 710 & 704 & 261 & 36 & 633 & 776 & 268 & 1,310 \\
\hline & 15 & 52 & 457 & 507 & 195 & 27 & 453 & 561 & 264 & 1,251 \\
\hline & 16 & 33 & 404 & 447 & 164 & 29 & 389 & 505 & 199 & 950 \\
\hline & 17 & 42 & 331 & 371 & 153 & 24 & 324 & 419 & 142 & 809 \\
\hline & 18 & 41 & 267 & 293 & 95 & 15 & 263 & 323 & 164 & 650 \\
\hline & 19 & 24 & 233 & 255 & 76 & 15 & 223 & 287 & 156 & 420 \\
\hline & Total & 443 & 674 & 671 & 333 & 16 & 640 & 702 & 142 & 1,573 \\
\hline \multirow[t]{11}{*}{ Girls } & 10 & 43 & 870 & 878 & 245 & 37 & 803 & 954 & 181 & 1,517 \\
\hline & 11 & 46 & 867 & 894 & 261 & 38 & 816 & 971 & 452 & 1,616 \\
\hline & 12 & 44 & 675 & 729 & 250 & 38 & 653 & 805 & 308 & 1,330 \\
\hline & 13 & 46 & 431 & 474 & 189 & 28 & 418 & 530 & 227 & 1,127 \\
\hline & 14 & 36 & 334 & 340 & 93 & 16 & 309 & 372 & 191 & 1,063 \\
\hline & 15 & 35 & 289 & 312 & 149 & 25 & 261 & 363 & 164 & 587 \\
\hline & 16 & 43 & 250 & 262 & 53 & 8 & 245 & 278 & 152 & 433 \\
\hline & 17 & 50 & 217 & 223 & 42 & 6 & 211 & 235 & 122 & 321 \\
\hline & 18 & 27 & 216 & 214 & 54 & 10 & 192 & 235 & 127 & 355 \\
\hline & 19 & 34 & 193 & 201 & 43 & 7 & 186 & 216 & 137 & 306 \\
\hline & Total & 404 & 328 & 473 & 316 & 16 & 442 & 504 & 122 & 1,616 \\
\hline
\end{tabular}


Table 2. Comparison of mean serum alkaline phosphatase levels based on age groups (U/L)

\begin{tabular}{crrrrc}
\hline Age (yr) & Boys & Girls & \multicolumn{1}{c}{$p$-value* } & $\mathrm{T}^{\dagger}$ & $\mathrm{T}^{\ddagger}$ \\
\hline 10 & 839 & 878 & 0.379 & $\mathrm{a}$ & $\mathrm{a}$ \\
11 & 934 & 894 & 0.443 & $\mathrm{a}$ & $\mathrm{a}$ \\
12 & 1,007 & 729 & $<0.001$ & $\mathrm{a}$ & $\mathrm{a}$ \\
13 & 962 & 474 & $<0.001$ & $\mathrm{a}$ & $\mathrm{b}$ \\
14 & 704 & 340 & $<0.001$ & $\mathrm{~b}$ & $\mathrm{~b}$ \\
15 & 507 & 312 & $<0.001$ & $\mathrm{~b}$ & $\mathrm{~b}, \mathrm{c}$ \\
16 & 447 & 262 & $<0.001$ & $\mathrm{~b}, \mathrm{c}$ & $\mathrm{c}$ \\
17 & 371 & 223 & $<0.001$ & $\mathrm{c}$ & $\mathrm{c}$ \\
18 & 293 & 214 & $<0.001$ & $\mathrm{c}$ & $\mathrm{c}$ \\
19 & 255 & 201 & 0.003 & $\mathrm{c}$ & $\mathrm{c}$ \\
Total & 671 & 473 & $<0.001$ & & \\
\hline
\end{tabular}

*Statistical significance was tested by t-test.

${ }^{\dagger}$ The same letters indicate non-significant difference between age groups based on Tukey's HSD multiple comparison test in boys.

${ }^{7}$ The same letters indicate non-significant difference between age groups based on Tukey's HSD multiple comparison test in girls.
해당하는 범위는 553 1,553 U/L, 12 13세의 경우에는 653 $1,518 \mathrm{U} / \mathrm{L}, 19 \sim 20$ 세의 경우에는 156 419 U/L로 나타났다. 여 아 11 12세의 경우 2.5 백분위수와 97.5 백분위수에 해당하는 범 위는 463 1,598 U/L, 12 13세의 경우에는 318 1,318 U/L, 19 20세의 경우에는 137 297 U/L로 나타났다(Table 3).

\section{고 찰}

참고치 설정을 위한 기초 자료를 제시하고자 10세 이상 20세 미 만 소아청소년의 연령과 성별에 따른 혈청 ALP의 활성치를 살펴보 았는데, ALP의 활성치는 성장과 관련이 있어 소아 청소년에서 그 수치가 높고, 여성에서는 12 세 이후 남성에서는 14 세 이후부터 감 소하여서 남성의 경우 16 18세경에 성인 농도에 도달하게 된다고 알려져 있다(Fleisher 등, 1977; Turan 등, 2011). 본 연구에서도

Table 3. Distribution of serum alkaline phosphatase levels according to the percentile based on age groups

\begin{tabular}{|c|c|c|c|c|c|c|c|c|c|c|}
\hline & \multirow{2}{*}{ Age (yr) } & \multicolumn{9}{|c|}{ Percentiles (U/L) } \\
\hline & & 2.5 & 5 & 10 & 25 & 50 & 75 & 90 & 95 & 97.5 \\
\hline \multirow[t]{11}{*}{ All } & 10 & 511 & 544 & 585 & 697 & 854 & 972 & 1,175 & 1,235 & 1,340 \\
\hline & 11 & 518 & 545 & 586 & 743 & 879 & 1,078 & 1,210 & 1,365 & 1,559 \\
\hline & 12 & 404 & 461 & 544 & 675 & 869 & 1,093 & 1,259 & 1,328 & 1,446 \\
\hline & 13 & 243 & 250 & 313 & 427 & 703 & 947 & 1,195 & 1,341 & 1,457 \\
\hline & 14 & 210 & 238 & 268 & 335 & 493 & 736 & 999 & 1,099 & 1,251 \\
\hline & 15 & 180 & 208 & 235 & 289 & 368 & 497 & 718 & 851 & 1,034 \\
\hline & 16 & 185 & 194 & 209 & 244 & 301 & 387 & 556 & 682 & 770 \\
\hline & 17 & 146 & 157 & 182 & 206 & 255 & 325 & 457 & 569 & 752 \\
\hline & 18 & 128 & 137 & 164 & 202 & 251 & 299 & 367 & 431 & 551 \\
\hline & 19 & 144 & 156 & 159 & 173 & 203 & 257 & 313 & 359 & 413 \\
\hline & Total & 161 & 184 & 207 & 268 & 486 & 835 & 1,073 & 1,202 & 1,300 \\
\hline \multirow[t]{11}{*}{ Boys } & 10 & 519 & 541 & 593 & 687 & 840 & 971 & 1,112 & 1,206 & 1,325 \\
\hline & 11 & 553 & 578 & 659 & 755 & 887 & 1,113 & 1,204 & 1,304 & 1,553 \\
\hline & 12 & 653 & 673 & 688 & 825 & 983 & 1,191 & 1,302 & 1,407 & 1,518 \\
\hline & 13 & 491 & 557 & 682 & 805 & 928 & 1,150 & 1,337 & 1,457 & 1,511 \\
\hline & 14 & 279 & 301 & 350 & 506 & 710 & 887 & 1,083 & 1,185 & 1,302 \\
\hline & 15 & 264 & 276 & 301 & 362 & 457 & 612 & 782 & 880 & 1,143 \\
\hline & 16 & 199 & 207 & 275 & 344 & 404 & 535 & 698 & 813 & 903 \\
\hline & 17 & 143 & 158 & 205 & 272 & 331 & 438 & 620 & 770 & 807 \\
\hline & 18 & 165 & 192 & 194 & 228 & 267 & 341 & 386 & 509 & 643 \\
\hline & 19 & 156 & 157 & 167 & 192 & 233 & 311 & 381 & 417 & 419 \\
\hline & Total & 192 & 212 & 262 & 367 & 674 & 912 & 1,149 & 1,250 & 1,314 \\
\hline \multirow[t]{11}{*}{ Girls } & 10 & 214 & 516 & 583 & 715 & 870 & 1,028 & 1,201 & 1,297 & 1,497 \\
\hline & 11 & 463 & 519 & 555 & 690 & 867 & 1,026 & 1,250 & 1,474 & 1,598 \\
\hline & 12 & 318 & 395 & 449 & 546 & 675 & 922 & 1,111 & 1,214 & 1,318 \\
\hline & 13 & 229 & 243 & 250 & 332 & 431 & 562 & 741 & 863 & 1,083 \\
\hline & 14 & 191 & 205 & 231 & 268 & 334 & 400 & 478 & 584 & 841 \\
\hline & 15 & 164 & 174 & 199 & 236 & 289 & 337 & 417 & 522 & 563 \\
\hline & 16 & 156 & 189 & 196 & 230 & 250 & 296 & 342 & 353 & 425 \\
\hline & 17 & 131 & 157 & 176 & 189 & 217 & 256 & 273 & 327 & 339 \\
\hline & 18 & 127 & 128 & 130 & 169 & 216 & 251 & 280 & 303 & 315 \\
\hline & 19 & 137 & 148 & 157 & 167 & 193 & 240 & 267 & 292 & 297 \\
\hline & Total & 156 & 168 & 189 & 236 & 328 & 673 & 971 & 1,129 & 1,227 \\
\hline
\end{tabular}


남아의 경우 $12 \sim 13$ 세에 가장 높은 활성치를 보였고, 13 세 이후부 터 감소하기 시작하였다. 여아의 경우는 $11 \sim 12$ 세에 가장 높고, 12 세 이후부터 감소하여 성장과 관련 있는 효소로서 연령에 따른 경 향을 다시 한 번 확인하였다.

David 등(2012)은 캐나다의 18세 이하 소아청소년 2188명을 대상으로 한 대규모 연구(Canadian Laboratory Initiative in Pediatric Reference Intervals, CALIPER)에서 40개의 혈중 지표 들의 연령.성별에 따른 참고범위를 제시하였는데, ALP의 경우 10 12세, 13 14세, 15 16세, 17 18세로 연령을 세분화하였고, ALP 활성치는 10 12세 경우에는 141 460 U/L로 남녀 모두 동 일하나, 13 14세 남아의 경우 127 517 U/L, 여아의 경우 62 $280 \mathrm{U} / \mathrm{L}$ 였고, 15 16세(남아 89 365 U/L, 여아 54 128 U/L), 17 18세 (남아 59 164 U/L, 여아 48 95 U/L)로 연령이 증가함 에 따라 감소하였다. Bowers와 McComb (1982)은 소아 청소년의 연령군을 1 9세, 10 14세, 15 19세로 나누었고, Amit 등 (2003)은 ALP 활성치의 경우 미국 소아 청소년 연령군을 10 11 세, 12 13세, 14 15세, 16 19세의 네 그룹으로 나누었으며, 참 고치는 성별에 따라 각각 다르게 명시하였다. 또한 Fischbach와 Zawta (1992)의 계산으로부터 도출한 참고범위 설정 시 7 12세, 13 17세로 나눈 경우도 있었다. 본 연구에서는 10 11세, 11 12 세를 제외한 나머지 모든 연령군에서 평균값의 차이를 보였고, 사후분석 결과 남아의 경우 10 13세, 14 16세, 17 19세 연령 군에서, 여아의 경우 10 12세, 13 15세, 16 19세 연령군에서 각각 비유의성이 검증되었다. 이로써 우리나라 소아청소년의 참고 범위 설정에는 성별에 따라 각각 세 그룹으로 나누고 참고 범위를 따로 제시하는 것이 타당할 것으로 보인다.

참고범위는 각 검사기관에서 그 대상자에 기초하여 분석법에 맞 는 분석 조건에 따라 자체적으로 설정해야 하는데(Tietz, 1983; DGKC, 1992; Fischbach와 Zawta, 1992), ALP 측정 시 기질로는 $p$-NPP를 사용하는 방법이 폭넓게 쓰이고 있으며, 주로 많이 쓰이 는 완충액의 종류에는 2-Amino-2-methyl-1-propanol (AMP) (Kay, 1930; King과 Armstrong, 1934; Bessey 등, 1946; Kind와 King, 1954; Bowers와 McComb, 1966), diethanolamine (DEA), Tris, and N-methyl-D-glucamine (MEG) 등 (Lewandrowski 등, 1992)이 있다. 현재 ALP 활성 측정법에 대한 표준 참고 방법은 없으 나 효소에 대한 임상검사 표준 기관 전문가 위원회(Clinical Laboratory Standards Institute Expert Panel on Enzymes; $\mathrm{CLSI} / \mathrm{EPE}$ )에서 그에 준하는 참고 방법으로 Bowers와 $\mathrm{McComb}$ 에 의한 kinetic $p$-NPP법을 제시하고 있다(Bowers와 McComb, 1975; 1982). 현재 우리나라의 경우 임상정도관리검사에 제시하는 ALP 검사코드는 총 6 개인데, 이 중에서 $p$-nitrophenyl phosphate
( $p$-NPP) \& 2-amino-2-methyl-1-propanol (AMP) buffer (IFCC, Bower-McComb)를 사용하는 기관이 전체의 $48.0 \%$ 로 가 장 사용 비율이 높았으며, P-NPP \& ethyl amino ethanol (EAE) buffer 29.9\%, P-NPP \& diethanolamine (DEA) buffer (GSCC, Bessey-Lowry) $18.6 \%$ 로 전체 기관의 약 $96.5 \%$ 에 해당하였고 그 외 4-aminoantipyrine을 사용하는 기관이 전체의 $0.3 \%$, 기타 검사 법이 $3.2 \%$ 를 차지한다고 하였다. 이 중에서 측정원리에 따른 변동이 가장 적은 측정법은 $p-\mathrm{NPP} \& \mathrm{EAE}$ buffer로 나타났다(KAQA, 2014). 본 연구는 $p$-NPP \& EAE buffer를 사용하여 분석한 자료에 의한 활성치 및 참고치의 분포이며 검사법과 시약이 다를 경우 참고 치 설정과 해석에 주의해야 하므로(Tietz 등, 1983), 부적합한 참고 범위의 사용으로 유아 및 청소년에서 종종 진단의 오류를 범하지 않 도록 해야 한다.

또한 참고범위 설정을 위한 CLSI 지침(2008)에 따르면, 건강한 집 단을 대상으로 한 결과의 분포에서 비모수적 방법(nonparametric method)으로 보통 2.5 백분위수와 97.5 백분위수 사이에 분포하는 95\% 범위로 규정하고 각 해당 범위의 $90 \%$ 신뢰구간도 권장하고 있 다. 본 연구에서 각 백분위수 (\%)에 따라 활성치의 분포를 살펴본 결 과, 남아 11 12세의 경우 2.5 백분위수와 97.5 백분위수에 해당하 는 범위는 553 1,553 U/L, 12 13세의 경우에는 653 1,518 $\mathrm{U} / \mathrm{L}, 19$ 20세의 경우에는 156 419 U/L로 나타났고, 여아 11 12 세의 경우 2.5 백분위수와 97.5 백분위수에 해당하는 범위는 463 1,598 U/L, 12 13세의 경우에는 318 1,318 U/L, 19 20세의 경우에는 137 297 U/L로 나타나 대략적인 활성치의 분포는 참고 할 수 있을 것이다. 그러나 연구 대상자의 수가 847명(남 443명, 여 404명)으로 전체 대상자의 참고 범위를 설정함에는 충분하나 연령 별 참고 범위로 사용하기에는 한계가 있으므로 더 많은 자료를 이용 하여 검증하는 것이 필요하다.

본 연구에서 10 세 이상 20 세 미만 소아청소년의 혈청 ALP의 참 고치 설정을 위한 기초 자료를 제시하고자 연령과 성별에 따른 활 성치를 살펴보았다. 혈청 ALP의 활성은 성별· 연령별 변화 양상이 다르므로 성인의 활성치와 달리 연령 또는 연령군별로 따로 설정되 어야함을 알 수 있었으며 본 연구에서 포함되지 않은 10 세 이하 소 아청소년의 자료를 보완하여 전체 소아청소년의 데이터를 구축하 면 추후 임상에서 유용하게 활용될 것이다.

\section{Acknowledgements: None}

Funding: None

Conflict of interest: None 


\section{References}

1. Amit K. Ghoshala, Steven J. Soldin. Evaluation of the Dade Behring Dimension RxL: integrated chemistry system-pediatric reference ranges. Clinica Chimica Acta. 2003, 331:135-146.

2. Bessey O, Lowry OH, Brock MJ. Method for the determination of alkaline phosphatase with five cubic millimeters of serum. $J$ Biol Chem. 1946, 164:321-329.

3. Bowers GN, McComb RB. A continuous Spectrophotometric method for measuring the activity of serum alkaline phosphatase. Clin Chem. 1966, 12:70.

4. Bowers GN, McComb RB. Measurement of total alkaline phosphatase activity in human serum. Clin Chem. 1975, 21: 1988-1995.

5. Bowers GN, McComb RB. Alkaline phosphatase, total activity in human serum. In: Faulkner WH, Meites S, eds. Selected Methods for the Small Clinical Chemistry Laboratory. 1982, p79-83. American Association for Clinical Chemistry. Washington, DC.

6. Clinical Laboratory Standards Institute (CLSI). Defining, establishing and verifying reference intervals in the clinical laboratory; proposed guideline. 3rd edition. CLSI document C28-A3. 2008, Wayne, Clinical Laboratory Standards Institute.

7. David AC, Lianna K, Man KC, Caitlin HD, Davor B, Allison AV, et al. Closing the Gaps in Pediatric Laboratory Reference Intervals: A CALIPER Database of 40 Biochemical Markers in a Healthy and Multiethnic Population of Children. Clin Chem. 2012, 58:854-868.

8. DGKC (Deutsche Gesellschaft für Klinische Chemie), Working Group on Enzymes. Proposal of standard methods for the determination of enzyme catalytic concentrations in serum and plas$\mathrm{ma}$ at $37^{\circ} \mathrm{C}$. I. Alkaline phosphatase (orthophosphoric-monoester phosphohydrolase, alkaline optimum, EC 3.1.3.1). Eur J Clin Chem Clin Biochem. 1992, 30:247-256.

9. Fischbach F, Zawta B. Age-dependent Reference Limits of Several Enzymes in Plasma at Different Measuring Temperatures. Klin Lab. 1992, 38:556-561.

10. Fleisher GA, Eickelberg ES, Elveback LR. Alkaline phosphatase activity in the plasma of children and adolescents. Clin Chem. 1977, 23:469-472.

11. Hausamen TU, Helger R, Rick W. Optimal conditions for the determination of serum alkaline phosphatase by a new kinetic method. Clin Chim Acta. 1967, 15:241-245.

12. Kaplan MM. Current concepts: Alkaline Phosphatase. New England J. Med. 1972, 286:200-202.

13. KAQA (Korean Association of Quality Assurance). http://www. lab-qa.org/, last visited on 20 June 2014.
14. Kay HD. Plasma phosphatase in osteitis deformans and in other diseases of the bone. BrJ Exp Pathol. 1929, 10:253.

15. Kay HD. Plasma phosphatase: I. Method of determination. some properties of the enzyme. J Biol Chem. 1930, 89:235-247.

16. Kind PRN, King EJ. Estimation of plasma phosphatase by determination of hydrolysed phenol with amino-antipyrine. J Clin Pathol. 1954, 7:322-326.

17. King EJ, Armstrong AR. A convenient method for determining serum and bile phosphatase activity. Can Med Assoc J. 1934, 31:376-381.

18. Kruse K, Bartels H, Gunther H. Serum alkaline phosphatase isoenzymes in childhood. Eur J Pediatr. 1977, 126:53-59.

19. Lewandrowski K, Lee-Lewandrowski E, Bowers GN Jr, McComb RB. Investigation of N-methyl-D-glucamine buffer for assay of alkaline phosphatase in serum. Clin Chem. 1992, 38:2286-2294.

20. Lott JA, Wolf PL. Clinical Enzymology: A Case-Oriented Approach. 1986, p57-74. Year Book Medical, Chicago.

21. Moss DW. A note on the spectrophotometric estimation of alkaline phosphatase activity. Enzymologia. 1966, 31:193-202.

22. Penttila IM, Jokela HA, Viitala AJ, Heikkinen E, Nummi S, Pystynen $\mathrm{P}$, et al. Activities of aspartate and alanine aminotransferases and alkaline phosphatase in sera of healthy subjects. Scand J Clin Lab Invest. 1975, 35:275-284.

23. Plomteux G, Reginster N. Measurement of the hepatic, intestinal and bony fractions of the serum alkaline phosphatase (author's transl). Ann Biol Clin (Paris). 1980, 38:215-222.

24. Robison R. The possible significance of hexosephosphoric esters in ossification. J Biochem. 1923, 17:286-293.

25. Schiele F, Henny J, Hitz J, Petitclerc C, Gueguen R, Siest G. Total bone and liver alkaline phosphatases in plasma: biological variations and reference limits. Clin Chem. 1983, 29:634-641.

26. Shinowara G, Jones LM, Reinhart HL. Estimation of serum inorganic phosphate and "acid" and "alkaline" phosphatase activity. J Biol Chem. 1942, 142:921-933.

27. Tietz NW, Burtis CA, Duncan P, Ervin K, Petitclerc CJ, Rinker $\mathrm{AD}$, et al. A reference method for measurement of alkaline phosphatase activity in human serum. Clin Chem. 1983, 29: 751-761.

28. Togari A, Sakai J, Matsumoto S, Nagatsu T. Highly sensitive assay for alkaline and acid phosphatase activity by high-performance liquid chromatography with electrochemical detection. J Chromatogr. 1987, 417:41-46.

29. Turan S, Topcu B, Gökçe I, Güran T, Atay Z, Omar A, et al. Serum alkaline phosphatase levels in healthy children and evaluation of alkaline phosphatase z-scores in different types of rickets. J Clin Res Pediatr Endocrinol. 2011, 3:7-11. 